\title{
ZASADY WSPÓŁŻYCIA SPOŁECZNEGO JAKO PODSTAWA ODMOWY DOKONANIA CZYNNOŚCI NOTARIALNEJ (UWAGI NA TLE ART. 81 PRAWA O NOTARIACIE)
}

1. Zgodnie z art. 1 ustawy z dnia 14 lutego $1991 \mathrm{r}$. Prawo o notariacie, ${ }^{1}$ notariusz jest powołany do dokonywania czynności, którym strony są obowiązane lub pragną nadać formę notarialną (czynność notarialna). Koreluje on z treścią art. 91 Prawa o notariacie analogicznie określającym zobowiązanie notariusza odnoszące się do spisania aktu notarialnego; akt notarialny jest sporządzany, jeżeli wymaga tego przepis prawa lub taka jest wola stron. Oba przepisy² są źródłem tzw. przymusu notarialnego $\mathrm{w}$ znaczeniu formalnym. Oznacza on obowiązek sporządzenia czynności notarialnej. ${ }^{3}$ Przymus notarialny w znaczeniu określanym jako materialny to wymóg zachowania odpowiedniej formy notarialnej w celu osiągnięcia określonego skutku prawnego. ${ }^{4}$ Skutek ten zostanie osiągnięty, gdy oprócz odpowiedniej formy, czynność będzie zgodna z obowiązującym prawem i zasadami współżycia społecznego (art. $353^{1}$ k.c.) czyli normami moralnymi, etycznymi obowiązującymi w danym społeczeństwie, a także innymi wymogami przewidzianymi przez przepisy. ${ }^{5}$

Konsekwencją przymusu notarialnego jest zakaz odmowy dokonania czynności poza przypadkami wprost wymienionymi w ustawie. Okolicznościami uzasadniają-

T. jedn. Dz.U. z 2014 r., poz. 164.

2 Z. Truszkiewicz jako podstawę przymusu notarialnego wskazuje art. $1 \S 1$, art. 81 oraz art. 83 Prawa o notariacie, zob. tenże, Tzw. przymus notarialny - podstawowy element instytucji notariatu, (w:) R. Sztyk (red.) III Kongres Notariuszy Rzeczypospolitej Polskiej. Referaty i opracowania. „Nowoczesny notariat w bezpiecznym państwie”, Warszawa-Kluczbork 2006, s. 377.

3 W. Boć, Status prawny notariusza, Łódź 2010, s. 131.

4 Ibidem, s. 130

$5 \quad$ Zob. w szczególności: A. Stelmachowski, Zarys teorii prawa cywilnego, Warszawa 1998, s. 63 i n., s. 109 i n.; M. Safjan, Klauzule generalne w prawie cywilnym, PiP 1990, nr 11, s. 48 i n.; Z. Radwański, M. Zieliński, (w:) M. Safjan (red.), System Prawa Prywatnego. Prawo cywilne - cz. ogólna, T. I, Warszawa 2007, s. 336 i n.; M. Pyziak-Szafnicka, (w:) M. Safjan (red.), System Prawa Prywatnego..., op. cit., s. 801; K. Pietrzykowski, (w:) K. Pietrzykowski (red.), Kodeks cywilny. Komentarz art. 1-44910, t. I, Warszawa 2013, s. 43; A. Zbiegień-Turzańska, (w:) K. Osajda (red.), Kodeks cywilny. Komentarz, T. I, Warszawa 2013, s. 310; M. Kuryłowicz, Etyczne podstawy notariatu, „Rejent” 2001, nr 5, s. 101 i n.; szerzej L. Petrażycki, Teoria państwa i prawa w związku z teorią moralności, t. I, Warszawa 1959. 
cymi odmowę są: sprzeczność z prawem zawieranej przez strony czynności prawnej (art. 81 Prawa o notariacie), bliski stosunek notariusza do strony (art. 84 Prawa o notariacie) oraz pojawiające się wątpliwości co do zdolności do czynności prawnych strony (art. 86 Prawa o notariacie). We wskazanych sytuacjach notariusz ma nie tylko prawo, ale i obowiązek powstrzymać się od sporządzenia czynności. Dodatkowo w $\S 20$ ust. 3 Kodeksu Etyki Zawodowej Notariusza ${ }^{6}$ została przewidziana możliwość odmowy dokonania czynności klientowi, który zachowuje się obraźliwie lub uniemożliwia notariuszowi godne wykonywanie zawodu. ${ }^{7}$

2. Przepisem o podstawowym znaczeniu dla istoty oraz funkcjonowania notariatu jest art. $2 \S 2$ Prawa o notariacie. Zawiera on nakaz dokonywania czynności notarialnych zgodnie z prawem. Jedynie przy zachowaniu tego wymogu dokument notarialny ma charakter dokumentu urzędowego (art. 2 § 3 Prawa o notariacie) i wywołuje skutki określone w art. $244 \S 1$ k.p.c. ${ }^{8}$ Natomiast uregulowanie art. 81 Prawa o notariacie jest następstwem wymogu art. $2 \S 2$ tej ustawy, zaś oba wyrażają fundamentalną zasadę demokratycznego państwa prawnego, jaką jest zasada legalizmu. Polega ona na zobowiązaniu podmiotów do działalności zgodnie z obowiązującym prawem $^{9}$ i ma swoje źródło w art. 7 Konstytucji. ${ }^{10}$ Organy władzy publicznej nie tylko działają na podstawie i w granicach prawa, ale także mają czuwać nad jego przestrzeganiem. Niewątpliwie to właśnie powinność zapewnienia legalności stanowi podstawową przyczynę udziału notariusza w najistotniejszych czynnościach prawnych z punktu widzenia państwa, jak i samych stron czynności prawnych. W literaturze podkreśla się rolę notariatu, który spośród wszystkich wolnych zawodów prawniczych w optymalny sposób wypełnia funkcję legalizmu. Zasada legalizmu nie ogranicza się wyłącznie do czynności notarialnych wymienionych w art. 79 Prawa o notariacie. Obejmuje wszelkie przejawy aktywności notariusza. Oprócz tworzonych dokumentów także czynności określane jako „okołonotarialne”, takie jak informowanie, projektowanie czy wykonywanie obowiązków płatniczych powinny pozostawać zgodne z prawem. ${ }^{11}$ Każdy aspekt pracy notariusza, wszystkie czynności podejmowane $\mathrm{w}$ kancelarii notarialnej związane z czynnościami notarialnymi, dokonywane przez notariusza, ale także przez pracowników kancelarii, powinny odbywać się na podstawie i zgodnie z obowiązującym prawem. W sprzeczności z za-

Uchwała Nr 19 Krajowej Rady Notarialnej z dnia 12 grudnia 1997 r. w sprawie Kodeksu Etyki Zawodowej Notariusza, wydana na podstawie art. $40 \S 1$ pkt. 7 ustawy Prawo o notariacie.

Należy zwrócić uwagę na spory dotyczące charakteru prawnego aktów w postaci kodeksów etycznych zawodów zaufania publicznego i kompetencji prawodawczej organów samorządów zawodowych, zob. W. Boć, Status prawny..., op. cit., s. 137 i n.; A. Bień-Kacała, Źródła prawa wewnętrznego w Konstytucji Rzeczypospolitej Polskiej z 1997 r., Toruń 2013, s. 338; wyrok TK z dnia 23 kwietnia 2008 r., SK 16/07, OTK-A 2008, nr 3, poz. 45; wyrok NSA z dnia 14 kwietnia 1997 r., II SA 633/96, ONSA 1998, nr 2, poz. 52; wyrok SN z dnia 26 lutego 2004 r., III SZ 2/03, OSNP 2004, nr 22, poz. 395.

Ustawa z dnia 17 listopada 1964 r., Kodeks postępowania cywilnego, t. jedn. Dz.U. z 2014 r., poz. 101 ze zm. Cz.W. Salagierski, B. Tymecki, Zasada legalizmu w postępowaniu notarialnym, „Rejent” 2005, nr 9, s. 249. Konstytucja Rzeczypospolitej Polskiej z dn. 2 kwietnia 1997 r., Dz.U. Nr 78, poz. 483 ze zm. W. Boć, Status prawny..., op. cit., s. 145. 
sadą legalizmu pozostaje uchwała Sądu Najwyższego z dnia 19 listopada 2010 r., ${ }^{12}$ w której Sąd uznał, że przy poświadczaniu własnoręczności podpisu na dokumencie notariusz nie ma obowiązku badania zgodności z prawem tego dokumentu. Ograniczenie roli notariusza przy czynności poświadczenia własnoręczności podpisu jedynie do sprawdzenia, czy podpis został złożony przez właściwą osobę może sprawić, że czynność notarialna zostanie sporządzona na dokumencie zawierającym czynność prawną nieważną z mocy samego prawa. Dodatkowo w sytuacji, w której treść dokumentu obejmuje oświadczenia nieprawdziwe, ośmieszające, obraźliwe wówczas można uznać, że doszło do naruszenia powagi i uchybienia godności zawodu notariusza. Zamieszczenie podpisu i pieczęci urzędowej notariusza na takim dokumencie nie powinno mieć miejsca. ${ }^{13}$

3. Zasada legalizmu znajduje swój wyraz w art. 81 Prawa o notariacie. Jest w nim zawarty podstawowy obowiązek dla funkcji prewencyjnej notariatu, jakim jest odmowa sporządzenia czynności notarialnej. Notariusz odmawia dokonania czynności notarialnej sprzecznej z prawem. Widoczna jest tu wadliwa redakcja przepisu. Nie jest prawidłowe sformułowanie ,czynność notarialna sprzeczna z prawem”. Czynność notarialna dokumentuje czynność prawną. To czynność prawna może być sprzeczna z prawem i wówczas notariusz powinien odmówić sporządzenia czynności notarialnej, której przedmiotem jest nieważna czynność prawna (art. 58 k.c.). Czynność notarialna zawsze musi być dokonana zgodnie z przepisami prawa o notariacie, aby można ją było uznać za czynność notarialną (art. 2 § 2 Prawa o notariacie). ${ }^{14}$ Problemy w praktyce może powodować określenie ,sprzeczność z prawem". W poprzednio obowiązujących przepisach ustrojowych notariatu były używane bardziej precyzyjne sformułowania, odwołujące się także do norm moralnych i etycznych. W rozporządzeniu z 1933 r., ${ }^{15}$ pierwszym polskim zunifikowanym prawie o notariacie w art. 64 zostało przyjęte, że notariuszowi nie wolno dokonywać czynności sprzeciwiających się prawu, porządkowi publicznemu lub dobrym obyczajom. Podobnie, wprost odwołanie do norm pozaprawnych znalazło się w art. 30 ustawy z dnia 25 maja 1951 r., ${ }^{16}$ tym razem stwierdzono, że państwowemu biuru notarialnemu nie wolno dokonywać czynności sprzecznych z prawem lub na-

12 III CZP 82/10, OSNC 2011, nr 6, poz. 62 z glosami J. Biernata i J. Grykiel.

13 Stanowisko, zgodnie z którym notariusz powinien odmówić poświadczenia podpisu na dokumencie prywatnym, zawierającym czynność prawną sprzeczną z prawem budzi wątpliwości także w doktrynie. Za odmową poświadczenia podpisu w takiej sytuacji opowiadają się Cz.W. Salagierski, B. Tymecki, Zasada legalizmu..., op. cit., s. 253; J. Biernat, Glosa do uchwały SN z dnia 19 listopada 2010 r., III CZP 82/10; zob. też R. Wrzecionek, Czynności notarialne w prawie spółek, Warszawa 2012, s. 101 i n.; A. Oleszko, Prawo o notariacie. Komentarz, cz. II, t. II, Warszawa 2012, s. 556 i n.

14 J. Masiubiński, Kilka uwag w sprawie zażalenia na odmowę dokonania czynności notarialnej oraz dopuszczalności skargi kasacyjnej w tej sprawie, „Rejent” 2013, nr 3, s. 84; A. Oleszko, Prawo o notariacie. Komentarz, Cz. I (art. 1-78), Warszawa 2011, s. 51; wyrok SN z dnia 30 maja 2000 r., IV CKN 36/00, OSNC 2000, nr 12, poz. 223.

15 Rozporządzenie Prezydenta RP z dnia 27 października 1993 r., Prawo o notariacie, Dz.U. Nr 84, poz. 609 ze zm.

16 Ustawa z dnia 25 maja 1951 r. Prawo o notariacie, t. jedn. Dz.U. z 1963 r. Nr 19, poz. 106 ze zm. 
ruszających zasady współżycia społecznego w Państwie Ludowym. Także naruszenie zasad współżycia społecznego, obok sprzeczności z prawem stanowiło podstawę odmowy sporządzenia czynności notarialnej z art. 50 ustawy z 24 maja 1989 r. ${ }^{17}$ $\mathrm{Na}$ gruncie obecnie obowiązującego art. 81 Prawa o notariacie pojawiają się wątpliwości, czy odmowa dokonania czynności notarialnej powinna nastąpić wyłącznie wówczas, gdy zamierzona przez strony czynność prawna jest niezgodna z przepisami prawa stanowionego (art. 87 Konstytucji), czy może należy także uwzględniać normy moralne i etyczne określane jako zasady współżycia społecznego. Skutkiem szerokiego ujmowania podstaw odmowy sporządzenia czynności notarialnej jest przede wszystkim zwiększenie ochrony stron czynności notarialnej oraz bezpieczeństwa prawnego. Trzeba zaznaczyć, że skuteczniejsza będzie także realizacja funkcji prewencyjnej notariusza, polegająca na zapobieganiu sporom i zapewnieniu bezpieczeństwa prawnego. W bardzo obrazowy sposób wskazał i podkreślił doniosłość tej funkcji W. Jaworski, porównując notariusza do funkcji lekarza - profilaktyka. Stwierdził, że działalność notariatu zmniejsza liczbę przypadków, w których realizacja porządku prawnego odbywa się przy udziale sądu cywilnego, a przez to notariat przyczynia się do wzrostu pewności stosunków prawnych. ${ }^{18}$ Zasadnym jest twierdzenie, że funkcja prewencyjna notariatu będzie należycie wypełniana, gdy przesłanki odmowy dokonania czynności notarialnej będą pokrywały się z okolicznościami powodującymi nieważność czynności prawnej wskazanymi w art. 58 k.c. Jest to jeden $\mathrm{z}$ argumentów przemawiających za szerokim ujęciem sformułowania „sprzeczna z prawem” na gruncie art. 81 Prawa o notariacie jako obejmującego także zasady współżycia społecznego.

Wśród przedstawicieli doktryny i w judykaturze wyraźnie zaznaczona jest tendencja do szerokiego rozumienia pojęcia „,sprzeczność z prawem” na gruncie art. 81 Prawa o notariacie. Jednak są też obecne wypowiedzi przeciwne. S. Rudnicki jest zdania, że nie można stawiać notariuszowi wymagań nierealnych i oczekiwać cenzury prewencyjnej narzucanej stronom wbrew ich woli, ograniczając ich autonomię w ocenie przewidywanych skutków i planowanych interesów. Autor uważa, że notariusz nie powinien dokonywać oceny, czy zamierzona przez strony czynność prawna jest zgodna z zasadami współżycia społecznego. Takie wymaganie wychodzi poza zakres pojęcia sprzeczności z prawem. Ważne jest, aby granice, których przekroczenie uzasadnia uznanie czynności notarialnej za sprzeczną z prawem były zawsze czytelne. ${ }^{19}$ Jednak większość przedstawicieli piśmiennictwa uważa, że podstawą od-

18 W. Jaworski, Reforma notariatu, Kraków 1929, s. 21 cyt. za: B. Tymecki, Notariat i czynności notarialne, Białystok 1988, s. 27-28. W okresie międzywojennym była bardzo akcentowana w doktrynie rola notariusza w zapobieganiu sporom, zob. T. Ereciński, Kilka uwag o pozycji ustrojowej notariusza, jego odpowiedzialności cywilnej, oraz sądownictwie dyscyplinarnym, „Rejent” 2006, nr 5, s. 46; R. Sztyk, Notariusz jako funkcjonariusz publiczny, „Rejent” 2006, nr 11, s. 29; wyrok TK z dnia 10 grudnia 2003 r., K 49/2001, OTK ZU 2003, nr 9A, poz. 101; uchwała SN z dnia 29 maja 1990 r., III CZP 29/90, OSNC 1990, nr 12, poz. 150. gląd ten uznaje za słuszny także J. Masiubiński, tenże, Kilka uwag..., op. cit., s. 84-85; A. Oleszko, Prawo o nota- 
mowy dokonania czynności notarialnej na gruncie art. 81 Prawa o notariacie powinna być oprócz sprzeczności z ustawą także sprzeczność z zasadami współżycia społecznego. ${ }^{20} \mathrm{Cz}$.W. Salagierski oraz B. Tymecki zakazem obejmują nie tylko sprzeczność z przepisami ustawy, zasadami współżycia społecznego, ale także z prawem zwyczajowym. ${ }^{21}$ Argumentem zwolenników szerokiego ujmowania pojęcia sprzeczności z prawem jest przede wszystkim zamieszczenie odwołania do zasad współżycia społecznego w treści art. 5 k.c. oraz art. $58 \S 2$ k.c. jako przyczyny nieważności czynności prawnej. P. Malinowski słusznie podnosi, że nie można uznać za prawidłowe takiego stanowiska, zgodnie z którym art. 81 Prawa o notariacie odmiennie traktuje czynności, jakie w myśl art. 58 k.c. dotknięte są jednakowo sankcją nieważności bezwzględnej. ${ }^{22}$

4. Sąd Najwyższy w uchwale z dnia 18 grudnia 2013 r. ${ }^{23}$ uznał, że określenie „sprzeczność z prawem” zawarte w art. 81 Prawa o notariacie obejmuje także sprzeczność z zasadami współżycia społecznego, zaś notariusz odmawia dokonania czynności notarialnej z powodu tej sprzeczności, jeżeli wynika ona z treści zamierzonej czynności lub okoliczności jej dokonywania. Jest to pierwsza wypowiedź Sądu Najwyższego, która zawiera bardzo gruntowną analizę poglądu wyrażonego $\mathrm{w}$ tezie uchwały. We wcześniejszych orzeczeniach ${ }^{24}$ poruszana problematyka nie była szczegółowo omawiana i ograniczała się jedynie do wskazania konieczności uwzględniania jako podstawy odmowy sporządzenia czynności notarialnej także za-

riacie. Komentarz, cz. II, t. I, Warszawa 2012, s. 302, 326; A. Oleszko, Staranność zawodowa notariusza a zarzut wadliwie sporządzonej czynności notarialnej, (w:) J. Gołaczyński, P. Machnikowski (red.) Współczesne problemy prawa prywatnego. Księga pamiątkowa ku czci Profesora Edwarda Gniewka, Warszawa 2010, s. 430. Zob. jednak A. Oleszko, Odmowa sporządzenia czynności notarialnej, „Rejent” 1996, nr 4-5, s. 46, gdzie Autor stwierdza, że „obecne uregulowanie wskazujące na zakaz dokonywania czynności sprzecznej z prawem nie zwalnia notariusza od oceny, czy w konkretnym przypadku nie zachodzi sprzeczność z zasadami współżycia społecznego", a także A. Oleszko, R. Pastuszko, Tryb dokonywania czynności notarialnych jako postępowanie o charakterze cywilnoprawnym, „Rejent” 2010, nr 7-8, s. 96. Wydaje się, że za wąskim rozumieniem pojęcia sprzeczności z prawem opowiada się także G. Bieniek, Notariusz w orzecznictwie Sądu Najwyższego, (w:) E. Drozd, A. Oleszko, M. Pazdan (red.), Rozprawy z prawa prywatnego, prawa o notariacie i prawa europejskiego ofiarowane Panu Rejentowi R. Sztykowi, Kluczbork 2007, s. 393-396.

20 A. Redelbach, Prawo o notariacie. Komentarz..., op. cit., s. 211; S. Wójcik, Wpływ notariusza na powstanie stosunków cywilnoprawnych z umów, (w:) Problematyka prawna reprywatyzacji notariatu polskiego, Poznań-Kluczbork 1996, s. 231; J. Budzianowska, Odmowa dokonania czynności notarialnej, „Nowy Przegląd Notarialny” 2000, nr 1, s. 47; P. Malinowski, Uwagi na temat formy oświadczeń woli i czynności prawnych dokonywanych między jednoosobową spółką a jej wspólnikiem, „Rejent” 2005, nr 5, s. 99; W. Boć, Status prawny..., op. cit., s. 145-146; Cz.W. Salagierski, B. Tymecki, Zasada legalizmu w postępowaniu notarialnym, op. cit., s. 251, 252; zob. też E. Gniewek, O uniwersalnej zasadzie przestrzegania prawa przez notariusza, (w:) II Kongres Notariuszy Rzeczypospolitej Polskiej. Referaty i opracowania, Poznań-Kluczbork, s. 54 i n.; M. Kuryłowicz, Etyczne podstawy..., op. cit., s. 109 i n.

21 Cz.W. Salagierski, B. Tymecki, Zasada legalizmu w postępowaniu notarialnym, op. cit., s. 251-252, zob. też S. Wójcik, Wpływ notariusza..., op. cit., s. 234-235.

22 P. Malinowski, Uwagi na temat..., op. cit., s. 99.

23 III CZP 82/13, uchwała wraz z uzasadnieniem dostępna jest opublikowana na stronach internetowych Sądu Najwyższego.

24 W uchwale SN z dnia 9 maja 1995 r., III CZP 53/95, Lex 563626, Sąd Najwyższy odwołał się do art. $353^{1}$ k.c., stwierdzając, że jeśli stosunek prawny nie sprzeciwia się wymienionym w tym przepisie wymogom to oznacza, że nie jest sprzeczny z prawem i w konsekwencji brak jest podstaw do odmówienia dokonania czynności przez notariusza na podst. art. 81 prawa o notariacie. Wyrok SN z dnia 5 lutego 2004 r., III CK 271/02, Lex 602711. 
sad współżycia społecznego. Na uwagę zasługuje postanowienie Sądu Apelacyjnego w Białymstoku z dnia 23 marca 2011 r., ${ }^{25}$ w którym szeroko zostały ujęte podstawy odmowy sporządzenia czynności notarialnej. Sąd ten odwołał się do art. $58 \S 1$ oraz $\S 2$ k.c. i uznał, że określenie „sprzeczność z prawem” z art. 81 Prawa o notariacie to nie tylko czynność sprzeczna $z$ ustawą, mająca na celu obejście ustawy lub sprzeczność z zasadami współżycia społecznego, ale stwierdził, że art. 81 obejmuje również czynność sprzeczną z prawomocnym orzeczeniem sądowym, kształtującym stan prawny między stronami. ${ }^{26}$ Jest to słuszny pogląd. Uwzględnia bowiem fakt, że nie tylko norma prawna pochodząca od uprawnionego do jej wydawania organu państwa kształtuje stan prawny między podmiotami, ale taki charakter mają również orzeczenia sądowe. Strony w umowie są zobowiązane urzeczywistnić rozstrzygnięcie sądu. Należy przy tym zauważyć, że notariusz będzie mógł powołać się na art. 81 Prawa o notariacie i odmówić sporządzenia czynności, jeśli strony okazały mu orzeczenie sadu. Podobnie jak w przypadku prawomocnych orzeczeń sadowych należy uznać, że także sprzeczność postanowień umowy (umowy finalnej) z wcześniej zawartą między stronami umową (umową pierwotną) może stanowić podstawę odmowy dokonania czynności notarialnej. Chodzi tu o sytuację, gdy umowa finalna jest zawierana w wykonaniu wcześniejszej umowy, a postanowienia umowy finalnej odbiegają od ustaleń zawartych i przyjętych w pierwotnej. Nie dotyczy to sytuacji, gdy strony zgodnie oświadczą w umowie finalnej, że zmieniają treść w taki sposób.

Sąd Najwyższy w tezie uchwały z dnia 18 grudnia 2013 r. zwrócił uwagę, że odmowa dokonania czynności notarialnej na podstawie sprzeczności z zasadami współżycia społecznego następuje nie tylko, gdy sprzeczność dotyczy treści czynności, ale także okoliczności jej dokonywania. Notariusz jest zobligowany do oceny motywów dokonywania czynności prawnej. Kontroli w aspekcie zgodności z powszechnie uznawanymi zasadami moralnymi i etycznymi podlega zatem także intencja i zamiar osiągnięcia określonych skutków prawnych w drodze podjętej przez strony czynności prawnej. Można posłużyć się stwierdzeniem, że notariusz czuwa nad tym, aby strony miały „czyste ręce” przy dokonywaniu czynności prawnej, aby nie tylko czynność prawna pozostawała zgodna z szeroko pojętym porządkiem prawnym, ale także zamiar i jej cel. Nie może mieć miejsca sytuacja, w której celem czynności prawnej jest ograniczenie uprawnień czy pogorszenie sytuacji np. dożywotnika czy podmiotu uprawnionego z tytułu służebności. Obowiązkiem notariusza $\mathrm{z}$ art. $80 \S 2$ Prawa o notariacie jest czuwanie nad należytym zabezpieczeniem praw i słusznych interesów osób trzecich, niebiorących udziału w czynności notarialnej. Naruszenie praw tych podmiotów jest niezgodne z zasadami współżycia społecznego. Podstawą odmowy sporządzenia takiej czynności jest wyłącznie art. 81 Prawa o notariacie. Sąd Najwyższy stoi na stanowisku, że art. 80 § 2 nie może stanowić pod- 
stawy odmowy sporządzenia czynności notarialnej, jedyną podstawą jest art. 81 przy spełnieniu przesłanek odmowy. ${ }^{27}$ Należy także zwrócić uwagę, że stanowisko Sądu Najwyższego wyrażone w uchwale z dnia 18 grudnia 2013 r. zwiększa obowiązki notariusza i zaostrza jego odpowiedzialność. Notariusz ponosi odpowiedzialność za szkodę wyrządzoną przez dokonanie czynności sprzecznej z prawem, w tym także za szkodę wyrządzoną sporządzeniem czynności sprzecznej z zasadami współżycia społecznego, zaś ocenie podlega oprócz treści czynności zamiar oraz intencja stron. Niezbędne jest jednak wystąpienie skutku, czyli szkody. Zgodnie z art. 49 Prawa o notariacie, notariusz odpowiada za niedołożenie szczególnej staranności, do jakiej jest zobowiązany. Jest to odpowiedzialność, jak stwierdza przepis, na zasadach ogólnych. ${ }^{28}$ Odczytanie rzeczywistego zamiaru stron nie jest zadaniem łatwym, można powiedzieć, że wymaga od notariusza nie tylko znajomości prawa, ale umiejętności odczytywania subtelnych sygnałów stron płynących z ich zachowania, zwrotów, czy nawet gestów tak, aby realnie ocenić ich rzeczywisty zamiar. Konieczna jest duża ostrożność notariusza, a nawet wręcz pewna podejrzliwość, która jednak nie może prowadzić do traktowania stron czynności jako osób potencjalnie mających zamiar pokrzywdzenia innych uczestników obrotu. Wydaje się, że tylko działając przezornie i rozważnie notariusz będzie mógł ocenić zamiar i cel stron. Równocześnie należy zauważyć, że ostrożność przy dokonywaniu czynności notarialnej, baczne obserwowanie stawających, ich zachowania i gestów powinno mieć miejsce zawsze. Przepis art. 86 Prawa o notariacie zakazuje dokonywania czynności notarialnej, jeżeli notariusz poweźmie wątpliwość, czy strona czynności notarialnej ma zdolność do czynności prawnej. Zgodnie z literalnym brzmieniem wystarczającą podstawą odmowy na podst. art. 86 Prawa o notariacie jest jakakolwiek wątpliwość co do posiadania przez stronę zdolności do czynności prawnych, a nie pewność co do braku tej zdolności. ${ }^{29}$ Można postulować, aby również istnienie wątpliwości co do sprzeczności z zasadami współżycia społecznego czynności prawnej powodowało odmowę sporządzenia czynności notarialnej. Niewątpliwie występuje tu konflikt interesów i wartości zachodzący między autonomią stron, uprawnieniem do kształtowania

27 Uchwała SN z dnia 9 maja 1995 r., III CZP 53/95, Lex 563626.

28 Zarówno w doktrynie, jak i orzecznictwie nie ma natomiast zgodności co do podstaw odpowiedzialności cywilnej notariusza, zob. wyrok SN z dnia 30 maja 2000 r., IV CKN 36/00, OSNC 2000, poz. 223; wyrok SN z dnia 12 czerwca 2002 r., III CKN 694/00, OSNC 2003, nr 9, poz. 124; wyrok SN z dnia 5 lutego 2004 r., III CK 271/02, Lex 602711; wyrok SN z dnia 7 kwietnia 2004 r., III SK 28/04, OSN APiUS 2005, nr 3, poz. 47; wyrok SA w Warszawie z dnia 17 grudnia 1998 r., I ACa 697/98, OSA 1999, nr 10, poz. 46; wyrok SA w Warszawie z dnia 15 lutego 2006 r., I ACa 897/05, OSA 2006, nr 4, poz. 40; W. Boć, Status..., op. cit., s. 259; M.K. Kolasiński, Odpowiedzialność cywilna notariusza, Warszawa 2005, s. 131 i n.; B. Lewaszkiewicz-Petrykowska, Uwagi o zasadach rządzących odpowiedzialnością notariusza, „Przegląd Sądowy” 1995, nr 2, s. 29; R. Greszta, Staranność zawodowa notariusza w zakresie realizacji obowiązku wyjaśniająco-doradczego, „Rejent” 2009, nr 10, s. 34; A. Redelbach, Prawo o notariacie. Komentarz..., op. cit., s. 151; M. Florczak, Odpowiedzialność cywilna notariusza, „Rejent” 1995, nr 4, s. 118; A. Oleszko, Prawo o notariacie. Komentarz, cz. I (art. 1-78), Warszawa 2011, s. 509; G. Bieniek, Notariusz w orzecznictwie..., op. cit., s. 389.

29 J. Budzianowska, Odmowa dokonania czynności notarialnej, „Nowy Przegląd Notarialny” 2000, nr 1, s. 54; W. Boć, Status prawny..., op. cit., s. 123; zob. też E. Gniewek, O potrzebie szczególnej ostrożności notariusza przy dokonywaniu czynności z udziałem osób starszych, „Rejent” 2000, nr 5, s. 214. 
swoich stosunków w ramach obowiązujących nakazów i zakazów a ochroną szeroko ujętego porządku prawnego przed istnieniem w obrocie potencjalnie nieważnej czynności prawnej. Jednak wydaje się, że priorytetem jest ochrona pozostałych uczestników obrotu. W doktrynie wskazuje się, że granice, których przekroczenie uzasadnia uznanie czynności notarialnej za sprzeczną z prawem, muszą być czytelne. Ta przejrzystość i czytelność nie zawsze ma miejsce przy naruszeniu zasad współżycia społecznego. Wynika to z samej istoty norm moralnych i etycznych. Prawo to nie tylko normy uchwalone przez uprawniony organ i zapisane w przepisach, prawem są także uniwersalne zasady, wartości przyjęte i akceptowane w danym społeczeństwie. Zgodnie z zasadą wyrażoną przez Justyniana ${ }^{30}$ prawo naturalne jest częścią prawa prywatnego, którego sama natura nauczyła wszystkie istoty żywe (Ius naturale est, quod natura omnia animalia docuit). Stąd też zasady moralne, etyczne nawet jeśli nie zostały wyrażone wprost $\mathrm{w}$ przepisach obowiązującego prawa, nadal są prawem, zaś postanowienia stron umowy, jakie pozostają w sprzeczności z podstawowymi zasadami, określanymi w Kodeksie cywilnym jako zasady współżycia społecznego pozostają także niezgodne z szeroko pojętym prawem, a w związku z tym nie powinny funkcjonować w obrocie. G. Radbruch wskazywał, że zasady prawa naturalnego są silniejsze od wszystkich przepisów prawnych; ustawa, która przeczy tym zasadom jest pozbawiona mocy obowiązującej. ${ }^{31}$

5. Sąd Najwyższy w uchwale z dnia 18 grudnia 2013 r. uzasadniając swoje stanowisko odwołał się do wykładni literalnej. Słusznie wskazał, że ustawodawca w art. 81 użył bardzo szerokiego określenia, jakim jest „sprzeczność z prawem”, a mógł jak w art. 58 k.c. posłużyć się zwrotem „,sprzeczność z ustawą” lub sprzeczności z przepisem ustawy czy sprzeczności z przepisem prawa. To by przemawiało za ograniczeniem podstaw odmowy sporządzenia czynności notarialnej wyłącznie do prawa stanowionego. Zdaniem Sądu Najwyższego użyty zwrot obejmuje także niezgodność z prawem zwyczajowym i zasadami współżycia społecznego. Byłoby właściwe, aby język, jakim posługuje się ustawodawca był precyzyjny, a używane sformułowania jednoznaczne, nie pozwalające na różne ich rozumienie. Natomiast gdy nie ma takiej precyzji, wówczas interpretacja wieloznacznych zwrotów powinna być zgodna w całym systemie prawa, a przynajmniej w obrębie jednej gałęzi prawa. Normy Prawa o notariacie nie mają jednolitego charakteru (można wskazać na grupę przepisów o charakterze administracyjnym, w tym procedury administracyjnej, procedury karnej, procedury cywilnej). Wywołuje to trudności w zakwalifikowaniu prawa o notariacie do jednej gałęzi prawa. Tradycyjnie jednak jest ono

30 Digesta lustiniani 1,1. Również Cycero De Republica II, 1; III, 13.

31 G. Radbruch, Pięć minut filozofii prawa, (w:) T. Gizbert-Studnicki, K. Płeszka, R. Sarkowicz, J. Stelmach, Współczesna teoria i filozofia prawa na zachodzie Europy. Wybór tekstów. Uniwersytet Jagielloński, Skrypty uczelniane nr 494, Kraków 1985, s. 48. 
zaliczane do postępowania cywilnego, ${ }^{32} \mathrm{w}$ znacznej mierze służy realizacji norm prawa cywilnego. Można więc wnioskować, że jeśli w art. 81 Prawa o notariacie zostało użyte sformułowanie ,sprzeczne z prawem”, zamiast zamieszczonego w art. 58 k.c. ,sprzeczne z ustawą", to zwrotów tych nie należy rozumieć w taki sam sposób. Przeciwnie, prawidłowe jest stwierdzenie, że art. 81 zawiera w swojej strukturze wszystkie sytuacje, o jakich mowa w art. 58 k.c. Notariusz powinien odmówić sporządzenia czynności, która jest sprzeczna z prawem materialnym. Zatem podstawą odmowy powinna być czynność niezgodna z ustawą, zasadami współżycia społecznego, a także mająca na celu obejście ustawy, choć wydaje się, że sprzeczność z zasadami współżycia społecznego obejmuje także czynność mającą na celu obejście ustawy.

Przepis art. 58 k.c. wprowadza sankcję nieważności bezwzględnej. Nie sposób jest pogodzić sankcji nieważnej bezwzględnie czynności prawnej z dopuszczalnością sporządzenia przez notariusza czynności notarialnej, która jest niezgodna z zasadami współżycia społecznego. Można stwierdzić, że postępując w ten sposób notariusz naraża strony wyłącznie na niepotrzebne koszty, jakie są związane z dokonaniem czynności notarialnej. Takie zachowanie notariusza jest nieetyczne. Przede wszystkim funkcjonowanie takiej czynności w obrocie zagraża bezpieczeństwu prawnemu. Sankcja nieważności bezwzględnej oznacza, że mimo istnienia zewnętrznych pozorów konkretnej czynności prawnej nie wywołuje ona zamierzonych skutków prawnych, każdy zainteresowany może powołać się na nieważność, a sąd jest zobowiązany uwzględniać ją z urzędu. Zatem w razie ewentualnego sporu sąd oddali powództwo, nie zgłębiając istoty tego sporu. Brak wywołania skutków prawnych w świetle prawa materialnego przemawia za koniecznością odmowy sporządzenia czynności notarialnej.

W literaturze notariusz jest określany jako ,sędzia braku sporu”, ${ }^{33}$ jako hybryda łącząca elementy publicznoprawne i prywatnoprawne. ${ }^{34}$ Analizie poddaje się pozycję ustrojową notariusza w systemie organów ochrony prawnej, traktuje się go jako podmiot jurysdykcji prewencyjnej. ${ }^{35}$ Zaznacza się, że notariusz wypełnia wewnętrzne funkcje państwa, zainteresowanego w stabilizowaniu najbardziej doniosłych stosunków cywilnych ze względu na interes samego państwa. ${ }^{36}$ Działalność notariusza jest sui generis działalnością państwową ${ }^{37}$ Również gwarancja bezpieczeństwa obrotu prawnego i jego wiarygodności jest wypełniana w imieniu państwa, a zewnętrznym przejawem tego jest posługiwanie się przez notariusza pieczęcią stuszko, Tryb dokonywania..., op. cit., s. 83 i n.; uchwała SN z dnia 29 maja 1990 r., III CZP 29/90, OSNCP 1990, nr 12, poz. 150, uchwała SN z dnia 1 czerwca 2007 r., III CZP 41/07.

A. Redelbach, Prawo o notariacie..., op. cit., s. 35.

A.J. Szereda, Rozważania..., op. cit., s. 100.

W. Boć, Status prawny..., op. cit., s. 75 i $n$.

A. Oleszko, Obrót cywilnoprawny w praktyce notarialnej i wieczystoksięgowej, Kraków 2003, s. 15.

A.J. Szereda, Rozważania..., op. cit., s. 99. Zob. też uchwałę Izby Cywilnej SN z dnia 4 maja 1935 r., C. Prez. 15/34, „Przegląd Notarialny” 1935, nr 13-14, s. 27-30 cyt. za: W. Boć, Status..., op. cit., s. 75. 
urzędową z wizerunkiem orła (art. 8 Prawa o notariacie). ${ }^{38}$ Tak ścisłe powiązanie notariusza z działalnością państwa, jego status prawny, funkcje i rola, jaką pełni w obrocie jednoznacznie przemawiają za niedopuszczalnością dokonywania czynności notarialnej dokumentującej czynność prawną, która byłaby sprzeczna z zasadami współżycia społecznego. W tym względzie należy także zwrócić uwagę na zadania notariusza, które kwalifikuje się do ścisłej ochrony prawnej, są to czynności stricte sądowe, jakie alternatywnie mogą być dokonywane zarówno przed notariuszem, jak i przed sądem. Nie jest wskazana odmienna kwalifikacja czynności dokonywanej przed sądem, a odmienna przed notariuszem. Bardzo ważnym argumentem przemawiającym za koniecznością uwzględnienia zasad współżycia społecznego jako podstawy odmowy sporządzenia czynności notarialnej jest możliwość poddania się rygorowi egzekucji w akcie notarialnym (art. 777 § 1 pkt 4 i 5 k.p.c.). Akt notarialny zawierający rygor egzekucyjny należy pod względem mocy prawnej traktować na równi z prawomocnym wyrokiem sądowym. Uzasadnione jest twierdzenie o skuteczności i bezpośredniej wykonalności aktu notarialnego, ${ }^{39}$ na którego podstawie, po zaopatrzeniu w klauzulę wykonalności jest prowadzona egzekucja. Nie jest dopuszczalna sytuacja, w której akt notarialny zawierający nieważną czynność prawną ze względu na jej sprzeczność z zasadami współżycia społecznego stanowi równocześnie podstawę dochodzenia roszczeń.

W ewidentnej sprzeczności z etycznymi podstawami działalności notariuszy pozostawałoby ewentualne sporządzanie czynności notarialnych, których przedmiotem jest czynność sprzeczna z zasadami współżycia społecznego. Przy powołaniu, notariusz składa ślubowanie, które nakłada na niego powinność postępowania zgodnie z zasadami godności, honoru, uczciwości. Ślubuje obowiązki wypełniać zgodnie z prawem i sumieniem (art. 15 Prawa o notariacie). Jest on zobowiązany do postępowania zgodnie ze złożonym ślubowaniem (art. 17 Prawa o notariacie). Ponadto, zgodnie z art. 50 Prawa o notariacie, notariusz odpowiada dyscyplinarnie za uchybienia powadze i godności zawodu. Dokonując czynności notarialnej, której przedmiotem jest czynność prawna sprzeczna z zasadami współżycia społecznego, a zatem sprzeczna z normami moralnymi i etycznymi, notariusz równocześnie naraża się na odpowiedzialność dyscyplinarną.

Jako sprzeczne z zasadami współżycia społecznego judykatura uznaje przykładowo umowę zawieraną w sytuacji nacisku na kontrahenta, aby wykorzystać jego wpływy i pozycję w związku z zajmowanym stanowiskiem, jak też czynność prawna, podjęta w celu uniknięcia skutków prawnych wywołanych przez ustawę, której uchwalenie w najbliższym czasie jest powszechnie spodziewane ${ }^{40}$ Natomiast sprzeczności takiej nie dostrzegł Sąd Apelacyjny w Krakowie w przypadku umowy,

38 R. Pastuszko, Prawo do wysłuchania w postępowaniu sądowym a obowiązek wyjaśniająco-doradczy notariusza, „Rejent” 2003, nr 5, s. 108-109.

39 W. Boć, Status..., op. cit., s. 82-84.

40 J. Budzianowska, Odmowa dokonania..., op. cit., s. 47 i orzeczenia tam powołane. 
w której świadczenia stron pozostawały w dysproporcji. ${ }^{41}$ Wydaje się, że różnice w określeniu przez strony wysokości wzajemnych świadczeń występują stosunkowo często w praktyce i są spowodowane różnymi okolicznościami, jak choćby potrzebą szybkiej sprzedaży nieruchomości. Nie należy również wykluczyć sytuacji, gdzie strony, chcąc zmniejszyć koszty związane z zawieraniem umowy przenoszącej własność nieruchomości w sposób zamierzony wskazują niższą niż rzeczywiście płaconą cenę nieruchomości. Wówczas notariusz powinien pouczyć strony o konsekwencjach wynikających z podania w akcie notarialnym niższej kwoty niż wartość rynkowa. Jednak nie można wykluczyć również sytuacji, w której zachowanie stron w sensie prawnym będzie kwalifikowane jako wyzysk (art. 388 k.c.). Stąd też konieczne jest zachowanie przez notariusza staranności i ostrożności oraz uzyskanie jak najszerszej informacji o powodach ustalenia ceny na niższym poziomie. Jest to o tyle istotne, że w piśmiennictwie można spotkać się z poglądem, zgodnie z którym wyzysk strony znajdującej się w trudnym położeniu materialnym, podobnie jak bezskuteczność względna czynności (art. 527 k.c., art. 59 k.c.) jest traktowany jako sprzeczność z prawem. ${ }^{42}$ Warto również wskazać na słuszny pogląd M. Allerhanda, który uznawał za sprzeczną z prawem czynność, która jest ważna z punktu widzenia obowiązujących przepisów, ale naraża stronę na niekorzystne dla niej skutki. ${ }^{43}$

Zgodnie z twierdzeniem S. Wójcika, notariusz może i powinien dokonywać czynności notarialnej jedynie zgodnie z prawem i zgodnych z prawem. Wynika to ze statusu prawnego notariusza i jego zadań jako osoby zaufania publicznego. Autor wskazuje, że czynność notarialna obejmująca czynność prawną nie może być sprzeczna z prawem materialnym jej dotyczącym. ${ }^{44}$ Zgodzić się również należy z poglądem E. Gniewka, który uważa, że wobec urzędowej funkcji osoby zaufania publicznego, notariusz jest ze szczególną mocą zobowiązany do przestrzegania obowiązującego prawa, ${ }^{45}$ ze względu na bezpieczeństwo obrotu prawnego powinien dokonywać czynności od razu skutecznej. ${ }^{46}$

6. Przepis art. 81 Prawa o notariacie ma charakter kategoryczny, co podkreślił Sąd Najwyższy w uzasadnieniu do wyroku z dnia 7 listopada 1997 r. ${ }^{47}$ Konsekwencją tego jest odmowa sporządzenia czynności notarialnej, stanowiąca obowiązek notariusza, jeśli w jego ocenie zamierzona przez strony czynność prawna narusza prawo. Co więcej, zdaniem Sądu Najwyższego także zgoda stron czynności, a nawet naleganie na jej sporządzenie mimo sprzeczności z prawem, nie ekskulpuje notariu-

\footnotetext{
41 Ibidem.

42 E. Gniewek, O uniwersalnej..., op. cit., s. 60.

43 M. Allerhand, Prawo o notariacie, Lwów 1934, s. 96 cyt. za: Cz.W. Salagierski, B. Tymecki, Zasada legalizmu..., op. cit., s. 252.

44 S. Wójcik, Wpływ notariusza na powstanie stosunków cywilnoprawnych z umów, (w:) Problematyka prawna reprywatyzacji notariatu polskiego, Poznań-Kluczbork 1996, s. 231 i n.

45 E. Gniewek, O uniwersalnej zasadzie..., op. cit., s. 45-46.

46 Ibidem, s. 60.

47 II CKN 420/97, OSNC 1998, nr 5, poz. 76.
} 
sza, a prowadzi jedynie do możliwości powołania się w procesie odszkodowawczym na przyczynienie się strony do wyrządzenia szkody (art. 362 k.c.). Odmowa sporządzenia czynności notarialnej nie ma charakteru ostatecznego. Podlega kontroli sądu. Notariusz jest zobowiązany poinformować strony o możliwości wniesienia zażalenia do sądu okręgowego właściwego ze względu na siedzibę kancelarii notarialnej. ${ }^{48}$

Sąd Najwyższy w uchwale z 18 grudnia 2013 r. podkreśla, że odmowa sporządzenia czynności notarialnej powinna nastąpić tylko wyjątkowo, gdy planowana czynność naruszałaby obowiązujący porządek prawny.

7. Łacińska zasada głosi: non omne quod licet honostum est. Oznacza, że nie wszystko co prawem dozwolone jest uczciwe i etyczne. Nie jest możliwe objęcie każdego typu zachowań, każdego postępowania w ramy norm prawnych, które umożliwiłyby kwalifikację, uporządkowanie i odróżnienie tego co dobre, słuszne i dozwolone od tego, co zabronione, zakazane. Szczególnie obecnie, gdy coraz bardziej widoczne jest odchodzenie czy spychanie uczciwości, szacunku do drugiego człowieka, honoru na drugi plan, konieczne jest sięganie do norm pozaprawnych, norm etycznych i moralnych, wartości, jakie od wieków były właściwe i charakterystyczne dla europejskiej kultury prawnej, mającej swoje źródła w wartościach chrześcijańskich, filozofii greckiej i prawie rzymskim. ${ }^{49}$ Wykształcone w prawie rzymskim zasady: uczciwie żyć (honeste vivere), drugiego nie krzywdzić (alterum non laedere) czy każdemu oddać to co mu się słusznie należy (suum cuique tribuere $)^{50}$ są zawsze niezmienne, aktualne i stanowią podstawy życia społecznego, są wręcz warunkiem koniecznym i niezbędnym codzienności, można uznać, że są gwarantem stabilności stosunków społecznych i prawnych. Nie są one wyrażone wprost w ustawie, ale są ich źródłem, podstawą. Odnajdujemy je przykładowo w przepisach o ochronie dóbr osobistych, odpowiedzialności odszkodowawczej, przepisach określających wykonywanie prawa własności (art. 140, art. 142 k.c.), zasadzie swobody umów. Notariusz, który działając jako osoba zaufania publicznego, wypełniając funkcję jurysdykcji prewencyjnej, zabezpieczając pewność i stabilność obrotu prawnego, zapobiegając powstawaniu sporom będzie należycie wykonywał te zadania wówczas, gdy zawieraną przez strony czynność będzie oceniał nie tylko przez pryzmat obowiązujących norm, ale także zasad współżycia społecznego, leżących u podstaw tych norm. Nie można sprowadzać notariusza wyłącznie do roli swoistego protokolanta czynności zawieranej przez strony. Powinien on aktywnie uczestniczyć przy kształtowaniu stosunków prawnych, tak aby były one zgodne z szeroko pojętym prawem. Celem zasad współżycia społecznego jest ochrona powszechnie

\footnotetext{
48 Zob. szerzej M. Maciejewski, Zażalenie na odmowę dokonania czynności notarialnej, „Przegląd Sądowy” 2000, nr 1, s. 81 i n.; R. Kapkowski, Odmowa dokonania czynności przez notariusza w aspekcie proceduralnym, „Rejent” 2008, nr 7-8, s. 40 i n.; J. Masiubiński, Kilka uwag..., op. cit., s. 83 i n.; Cz.W. Salagierski, B. Tymecki, Zasada legalizmu..., op. cit., s. 253 i $n$.

49 M. Kuryłowicz, Etyczne..., op. cit., s. 102-103.

$50 \quad$ Ibidem.
} 
Zasady współżycia społecznego jako podstawa odmowy dokonania czynności notarialnej...

akceptowanych w społeczeństwie wartości. Mają one wyjątkowe zastosowanie, ograniczone do sytuacji, gdy przepisy prowadzą do zjawisk nie do zaakceptowania z punktu widzenia relacji między członkami społeczeństwa. 


\section{PRINCIPLES OF COMMUNITY LIFE COEXISTENCE AS A BASIS FOR REFUSAL TO PERFORM NOTARIAL ACTIONS (REMARKS ON ARTICLE 81 OF NOTARY LAW)}

The duty of a notary is to perform notary actions in accordance with the law (Art. $2 \S 2$, Notary Law). Categorically, Art. 81, Notary Law, demands refusal to perform a notarial action when such action would be illegal. Doubts emerge, however, as to whether this refusal rule should only be followed when a legal transaction intended by the parties is inconsistent with statutory law or whether moral and ethical norms, defined as the principles of community life/social coexistence, should also be considered. Primarily, widening recognition of the grounds for refusal to prepare a notary, increases protection to the parties engaged in a legal transaction. The notary's preventative function would become more efficient. A wider interpretation of the phrase "contrary to the law" is in accordance with Art. 58 §, Criminal Code, which introduces the sanction of absolute nullity for legal transactions contrary to the principles of community life coexistence.

Keywords: Notary Law, principles of community life/social coexistence, moral and ethical norms, notary actions, notary's preventative function 